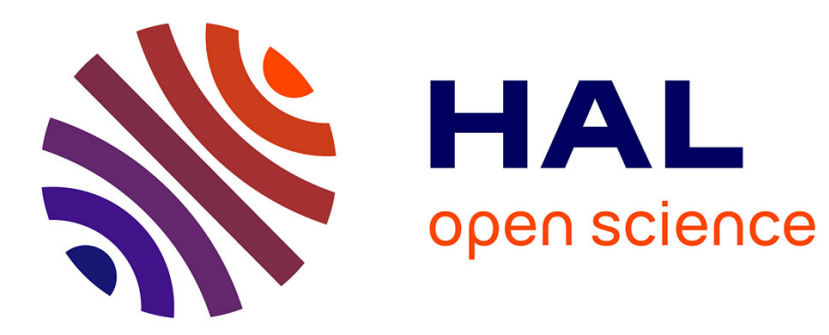

\title{
Applying Competence Structures for Peer Tutor Recommendations in CSCL Environments.
}

Jürgen Heller, Cord Hockemeyer, Dietrich Albert

\section{To cite this version:}

Jürgen Heller, Cord Hockemeyer, Dietrich Albert. Applying Competence Structures for Peer Tutor Recommendations in CSCL Environments.. IEEE International Conference on Advanced Learning Technologies (ICALT'04), 2004, Joensuu, Finland. pp.1050-1051. hal-00190249

HAL Id: hal-00190249

https://telearn.archives-ouvertes.fr/hal-00190249

Submitted on 23 Nov 2007

HAL is a multi-disciplinary open access archive for the deposit and dissemination of scientific research documents, whether they are published or not. The documents may come from teaching and research institutions in France or abroad, or from public or private research centers.
L'archive ouverte pluridisciplinaire HAL, est destinée au dépôt et à la diffusion de documents scientifiques de niveau recherche, publiés ou non, émanant des établissements d'enseignement et de recherche français ou étrangers, des laboratoires publics ou privés. 


\title{
Applying Competence Structures for Peer Tutor Recommendations in CSCL Environments
}

\author{
Jürgen Heller, Cord Hockemeyer, Dietrich Albert \\ University of Graz, Austria
}

\begin{abstract}
Competence structures of the content and competence modelling of the learners provide well-suitable means for finding appropriate peer tutors in CSCL based on asynchronous messaging and annotations. Various criteria for the appropriateness of potential peer tutors can be discussed. An internet-based system used as a large scale Web experiment can then also deliver data for evaluating such criteria.
\end{abstract}

\section{1: Introduction}

An important issue in CSCL is the selection of peer tutors or other co-learners for a student. In this paper, we will focus on peer tutoring based on public annotations to documents in an e-Learning course delivered through the Web. This approach connects Hoppe's [10] formalisation of peer selection criteria and Inaba and Okamoto's [11, 12] concept of utterance classification with the theory of knowledge spaces which facilitates personalised eLearning through the application of prerequisite structures.

\section{2: Theoretical background}

\section{1: Peer selection}

Hoppe [10] has formally described the selection of collaboration groups based on the student modelling within an e-Learning system and on the system's knowledge about the problem to be solved within the group. In case of peer tutoring, the tutor should be able to solve the tasks whereas the tutored person has some difficulties. In case of collaborative problem solving, all necessary knowledge should be available in the group while no member has all needed knowledge on their own.

\section{2: Utterance classification}

Inaba and Okamoto $[11,12]$ have presented an eLearning system which allows the learners to add their utterances (questions, answers, comments, etc.) as classified, public annotations to an existing course. A learner publishing such an utterance has to specify the type of it.
In case of comments, this includes also the specification whether the comment is an agreement or a contradiction.

\section{3: Knowledge space theory}

The theory of knowledge spaces was developed by Doignon and Falmagne [5,6] originally aiming at the adaptive assessment of knowledge. In the meantime, however, its major application lies in the field of e-Learning.

If a domain of knowledge is described through a set of test items, there will often exist prerequisite relationships between these items, i.e. if a student is capable of solving a certain item $a$, we can surmise that this student is also capable of solving some other item $b$. Such prerequisite structures can be used for inferences for adaptive testing. If a prerequisite structure contains also lessons, we can use the lessons and items together with the structure for personalised e-Learning [2]. This approach has been applied in the development of the RATH (Relational Adaptive Tutoring Hypertext) system [9].

In an extension of knowledge space theory, the group around Albert and Lukas [1,3] introduced a clear distinction between concrete learning objects and abstract, latent competencies (or skills). Such a distinction supports the development of adaptive e-Learning systems with highly reusable content including the structure information through metadata usage $[4,8]$.

\section{3: The $C^{2}$ RATH concept}

\section{1: Collaborative RATH (CRATH)}

Based on the experiences with RATH and on the results of Hoppe and of Inaba and Okamoto, the concept of a collaborative RATH system was developed. In RATH, the knowledge of a learner is modelled as the set of learning documents the learner has read and the set of items s/he has solved [9].

In the collaborative RATH concept study [7], a learner would be able to add public annotations to a document. Such an annotation would be classified as described in Section 2.2. In case of a question, the system would select some other learners with an appropriate knowledge state and ask for their willingness to answer the question. On the other side, whenever some learner gives an annotation to an existing annotation, the author of that original anno- 
tation would be notified.

One factor in the selection of appropriate co-learners would also be the online-status, i.e. a potential peer who is currently online would be preferably selected in order to ensure a rapid answer to a question.

The appropriateness of a peer may well have criteria beyond those of Hoppe. One might, e.g., prefer peers who share much knowledge with the asking learner. This would allow for analogies drawn by the peer to be understood by the asking student.

\section{2: Collaborative, Competence-based RATH (C RATH)}

One disadvantage of the RATH system is its document-focused approach. Whenever the documents in a course change (including the addition of new and the elimination of existing documents), prerequisite information for other, unchanged documents may also change. This makes it quite difficult to maintain a RATH course [4].

The APeLS system $[4,8]$ provides a solution for this through the separation of learning objects and abstract concepts or competencies. For a learning object in APeLS, the prerequisite objects are specified indirectly through prerequisite competencies.

Introducing the competence approach into the CRATH idea would provide the same advantages as the development from RATH to APeLS. The student model includes the competencies acquired by the respective learner. However, for selecting appropriate peers, the set of documents read by both learners would still be important: the peers selected do not necessarily have to have read the very document under discussion. Actually, it will often be helpful if a peer has (also) another access to the competencies taught in that document.

\section{4: Discussion}

We have proposed an approach for peer selection in a competency-based learning environment. This approach has, of course, to be implemented and tested for its feasibility in practice.

Once such a system exists and its feasibility has been proven, it may furthermore be used to investigate different criteria for peer selection. So far, there has been not much research on which criteria are best for this selection, and a system open for varying them can be an important research tool into this direction.

\section{Acknowledgements}

Part of this work was supported by the European Commission through a Marie Curie Fellowship to the second author (Grant no. ERBFMBICT983377).

\section{References}

[1] Albert, D. (Ed.). (1994). Knowledge structures. New York: Springer Verlag.

[2] Albert, D., \& Hockemeyer, C. (2002). Applying Demand Analysis of a Set of Test Problems for Developing an Adaptive Course. Proceedings of the International Conference on Computers in Education ICCE 2002 (pp. 69-70). Los Alamitos: IEEE Computer Society.

[3] Albert, D. \& Lukas, J. (Eds.). (1999). Knowledge spaces: Theories, empirical research, applications. Mahwah, NJ: Lawrence Erlbaum Associates.

[4] Conlan, O., Hockemeyer, C., Wade, V., \& Albert, D. (2002). Metadata Driven Approaches to Facilitate Adaptivity in Personalized eLearning systems. The Journal of Information and Systems in Education, 1, 38-44.

[5] Doignon, J.-P. \& Falmagne, J.-C. (1985). Spaces for the assessment of knowledge. International Journal of ManMachine Studies, 23, 175-196.

[6] Doignon, J.-P. \& Falmagne, J.-C. (1999). Knowledge spaces. Berlin: Springer_Verlag.

[7] Hockemeyer, C. (2000). CRATH: A Collaborative Adaptive Tutoring Hypertext System (Unpublished Technical Report). Institut für Psychologie Karl-Franzens-Universität Graz, Austria.

[8] Hockemeyer, C., Conlan, O., \& and Albert, V. W. D. (2003). Applying Competence Prerequisite Structures for eLearning and Skill Management. Journal of Universal Computer Science, 9, $1428-1436$.

[9] Cord Hockemeyer, Theo Held, and Dietrich Albert. RATH - a relational adaptive tutoring hypertext WWW-environment based on knowledge space theory. In Christer Alvegård, editor, CALISCE 98: Proceedings of the Fourth International Conference on Computer Aided Learning in Science and Engineering, pp. 417-423, Göteborg, Sweden, June 1998. Chalmers University of Technology.

[10] Hoppe, H. U. (1995). The use of multiple student modeling to parameterize group learning. In J. Greer (Ed.), Artificial Intelligence in Education, 1995 (pp. 234-241). Charlottesville, VA: Association for the Advancement of Computing in Education (AACE).

[11] Inaba, A. \& Okamoto, T. (1995). The network discussion supporting system embedded computer coordinator at the distributed places. Educational Technology Research, 18, 17-24.

[12] Inaba, A. \& Okamoto, T. (1997). The intelligent discussion coordinating system for effective collaborative learning. In T. Okamoto \& P. Dillenbourg (Eds.), Collaborative Learning/Working Support System with Networking (pp. 26-33). Kobe, Japan. Workshop at the 8th World Conference on Artificial Intelligence in Education AI-ED 97. 